\title{
Prolonged Moderate Hyperoxia Induces Hyperresponsiveness and Airway Inflammation in Newborn Rats
}

\author{
DELPHINE DENIS, MICHAEL JOHN FAYON, PATRICK BERGER, MATHIEU MOLIMARD, \\ MANUEL TUNON DE LARA, ETIENNE ROUX, AND ROGER MARTHAN \\ Pediatric Intensive Care and Pulmonology Units, Hôpital Pellegrin-Enfants, Place Amélie Raba Léon, \\ 33076 Bordeaux Cedex, France [D.D., M.J.F.]; and Laboratoire de physiologie cellulaire respiratoire, \\ INSERM E-9937 - Université Victor Segalen Bordeaux 2, 146 rue Léo Saignat, 33076 Bordeaux Cedex, \\ France [D.D., M.J.F., P.B., M.M., M.T.D.L., E.R., R.M.]
}

\begin{abstract}
Bronchopulmonary dysplasia is the most common cause of chronic pulmonary disease in premature infants. Airway inflammation appears to play a major pathogenetic role together with barotrauma and oxygen toxicity. The aim of the present study was to determine the effect of a 15-d exposure to moderate hyperoxia $\left(\mathrm{Fio}_{2}, 50 \%\right)$ on airway reactivity and inflammatory response in neonatal and adult rats. We studied in isolated tracheal rings the 1 ) isometric contraction to cumulative concentrations of carbachol $\left(10^{-8}\right.$ to $\left.\left.10^{-3} \mathrm{M}\right) ; 2\right)$ epithelial, submucosal, smooth muscle, and connective tissue surface area; and 3) distribution of inflammatory cells (mastocytes, granulocytes, macrophages) by using MAb. Reactivity to carbachol was significantly increased in the hyperoxic pups, in which a $13 \%$ increase in tracheal smooth muscle surface area was observed. Type-I mast cells and macrophages (submucosa and connective tissue) and granulocytes (connective tissue) were increased in the
\end{abstract}

\section{ABSTRACT}

neonatal hyperoxic group. Hyperoxia did not influence functional, morphometric, or cellular data in adult rats. In conclusion, exposure of newborn rats to moderate hyperoxia induces airway hyperresponsiveness and histologic changes similar to those reported in bronchopulmonary dysplasia. Hyperresponsiveness may be ascribed to an increase in smooth muscle related to the release of yet undetermined mediators by inflammatory cells infiltrating the airways. Lung immaturity definitely plays a role because similar alterations are not observed in adult rats. (Pediatr Res 50: 515-519, 2001)

\section{Abbreviations}

BPD, bronchopulmonary dysplasia

Fio $_{2}$, fraction of inspired oxygen

$\mathbf{O}_{2}$, oxygen

RMCP-I and II, rabbit anti-rat mast cell protease I and II
BPD, the most common chronic obstructive pulmonary disease in children, develops mostly in premature infants who require prolonged ventilation and/or $\mathrm{O}_{2}$ therapy (1). Airway hyperreactivity, which can persist into adolescence, is recognized as one of the long-term sequelae of this condition.

Despite improved neonatal care, including surfactant therapy and new ventilation modalities such as high-frequency oscillation, the incidence of BPD is increasing. The precise etiology of the disease remains unclear. Barotrauma related to ventilation induces airway remodeling and hyperreactivity by overdistension of lung tissue (2). However, hyperoxia, which causes more significant physiologic, inflammatory, and histologic changes than barotrauma alone, may play a critical role in

Received September 19, 2000; accepted March 1, 2001

Correspondence: Michael Fayon, M.D., M.Sc., Service de Réanimation Pédiatrique, Hôpital Pellegrin-Enfants, Place Amélie Raba Léon, 33076 Bordeaux Cedex, France; e-mail: michael.fayon@chu-bordeaux.fr

Supported by L'association Bordelaise pour l'avancement des sciences pédiatriques (ABASP). the etiology of airway hyperreactivity related to BPD (3). Similar to asthma, pulmonary inflammation is believed to play an important role in the pathogenesis of chronic lung disease. Histologic features of infants dying from BPD include submucosal edema, chronic inflammation, squamous metaplasia of epithelial cells in large and small airways, thickening of airway smooth muscle, and peribronchiolar fibrosis (4).

In the past, various hyperoxic models have been studied. In most instances, high $\mathrm{FiO}_{2}(>90 \%)$ for short exposure times $(<8$ d) has been used $(5,6)$. Such protocols have induced morphologic (airway smooth muscle thickening) as well as functional (increased airway hyperresponsiveness) changes in young 21-d-old rats (7). However, such protocols did not address the specific issue of lung immaturity because similar effects were observed in the adult rat (7). Moreover, such conditions of exposure to hyperoxia do not correspond to the present-day realities in an intensive care unit. Premature babies usually benefit from much lower levels of $\mathrm{Fio}_{2}$ for a longer period of time. 
The aim of the present study was to assess the combined effect of immaturity and realistic (i.e. moderate but prolonged) hyperoxia on airways. We have established an animal model of BPD induced by prolonged but moderate hyperoxia in the newborn rat. We have examined the impact of such exposure on airway reactivity, morphology, and inflammation and have observed that, under these conditions, hyperoxia-induced alterations were restricted to newborn rats.

\section{METHODS}

Exposure to hyperoxia. All animals were housed in our animal laboratory, which is approved by our Institutional Board. For each series of experiments, pregnant pathogen-free Wistar rats of known gestational age were purchased. After parturition in the laboratory, the pups were redistributed at random between the mothers. Within $24 \mathrm{~h}$ of birth, the pups were either exposed to moderate hyperoxia $\left(50 \% \mathrm{O}_{2}\right)$ or normoxia $\left(21 \% \mathrm{O}_{2}\right)$ at ambient pressure (sea level) for $15 \mathrm{~d}$ in standard cages placed within 86-L capacity Plexiglas isolation chambers (Roller 6 Rothos Sundis, France). This level of exposure, which is in contrast to most previous studies $\left(\mathrm{FiO}_{2} \geq\right.$ $95 \%$ for $8 \mathrm{~d})(5,8)$, was chosen to take into account the change in the way $\mathrm{O}_{2}$ is now given to neonates in clinical practice (9). They were housed with one nursing mother during the entire exposure time.

In the hyperoxic group, the $\mathrm{O}_{2}$ fraction in the closed-circuit chambers was maintained at a constant value of $50 \pm 1 \%$ by continuous monitoring using an oxygen analyzer (Servomex $\mathrm{O}_{2}$ Analyzer 580A, England) that controlled an electric valve at the output of the $\mathrm{O}_{2}$ tank. Gas circulation was facilitated by an air pump (3.5 L/min). In the control group, rats were housed in a similar chamber, and ambient air was continuously flushed through the control chambers via an identical air pump. Mothers were given food and water ad libitum. Cages were removed from the isolation chambers for 5 min every day to ensure servicing. Moisture and $\mathrm{CO}_{2}$ were absorbed with silica gel and soda lime (Prolabo, France), respectively, and both were changed every day. Pairs of adult rats were also exposed either to hyperoxia or normoxia for $15 \mathrm{~d}$ under the same conditions as rat pups.

Isometric contraction measurement. On d 15, the animals were removed from their chambers and anesthetized by intraperitoneal administration of ethyl carbamate (pups, $80 \mathrm{mg}$; adult rats, $1 \mathrm{~g}$ ). The body weight of each pup was then recorded. The trachea was rapidly excised, discarded of its connective tissue, and immediately placed in Krebs-Henseleit $(\mathrm{KH})$ solution $\left(\mathrm{NaCl}, 118.4 \mathrm{mM} ; \mathrm{KCl}, 4.7 \mathrm{mM} ; \mathrm{CaCl}_{2} \cdot 2 \mathrm{H}_{2} \mathrm{O}\right.$, $2.5 \mathrm{mM} ; \mathrm{MgSO}_{4} .7 \mathrm{H}_{2} \mathrm{O}, 1.2 \mathrm{mM} ; \mathrm{KH}_{2} \mathrm{PO}_{4}, 1.2 \mathrm{mM} ; \mathrm{NaHCO}_{3}$, $25 \mathrm{mM}$; D-glucose, $11.1 \mathrm{mM}$ ).

Each pup trachea was studied as a single segment due to its small size. Each trachea was resected into a 7-mm long ring so as to decrease variability in force generated as a result of unequal longitudinal smooth muscle content. In contrast, adult tracheas were cut into four rings of similar length $(4 \mathrm{~mm})$. They were mounted in an isolated organ bath system filled with $\mathrm{KH}$ solution, bubbled with $95 \% \mathrm{O}_{2}-5 \% \mathrm{CO}_{2}$, and maintained at $37^{\circ} \mathrm{C}$ as previously described (10). After a 60 -min equilibration period, each preparation was preloaded at the optimal resting tension $\left(\mathrm{L}_{0}=\right.$ tension that allows the maximal reproducible active force generation) (11). $\mathrm{L}_{0}$ was determined by generating a resting tension-force generation curve using acetylcholine $\left(10^{-3} \mathrm{M}\right)$ (Sigma Chemical Co., Saint-Quentin-Fallavier, France) in both normoxic and hyperoxic pups. $\mathrm{L}_{0}$ corresponded to a passive load of $1750 \mathrm{mg}$ in normoxic pups and $2000 \mathrm{mg}$ in hyperoxic pups; $\mathrm{L}_{0}$ for adult rats was found to be at $2000 \mathrm{mg}$ in both groups. A cumulative concentration-response curve to carbachol from $10^{-8}$ to $10^{-3} \mathrm{M}$ (Sigma Chemical Co., SaintQuentin-Fallavier, France) was then constructed. For each ring, the contractile response to carbachol was expressed both as active force (in $\mathrm{mg}$ ), i.e. the total force minus the resting tension, and as stress $\left(\mathrm{g} / \mathrm{mm}^{2}\right)$, i.e. the active force divided by muscle cross-sectional area.

$\mathrm{E}_{\max }$, which depicts the maximal active force generated (final plateau on the cumulative concentration-response curve), and $\mathrm{EC}_{50}$, the concentration of agonist producing half-maximal response, were calculated for each curve. $\mathrm{EC}_{50}$ was calculated by nonlinear curve fitting using a logistic function and expressed as $\log \mathrm{EC}_{50}$.

Morphologic study. Subsequent to the organ bath study, both control tissues and tissues from hyperoxic animals were embedded in glycolmethacrylate (GMA) (see below) and cut into $2-\mu \mathrm{m}$ thick sections perpendicular to the long axis. For the morphometric study, sections were stained with toluidin blue. Light microscopy was performed using an Optiphot microscope (Nikon, Tokyo, Japan). A compartmental analysis was performed delineating epithelium, conjunctive tissue, submucosa, and smooth muscle layer. The area $\left(\mu \mathrm{m}^{2}\right)$ and epithelium thickness $(\mu \mathrm{m})$ (layer area divided by the length of the epithelial basement membrane) were calculated using a video interactive display system $(\times 40$ magnification $)$ and an appropriate software (Quancoul, Quant'Image 1995-7, France) as previously described (12). Mean tracheal smooth muscle crosssectional area (n) was determined from the data obtained in three nonadjacent sections of the same trachea performed perpendicularly to the long axis of the specimen.

Sample processing for immunohistochemistry. The tracheal specimens embedded in GMA were also used for immunostaining as described previously $(12,13)$. The GMA sections were cut at $2-\mu \mathrm{m}$ thickness perpendicular to the long axis with an ultramicrotome and incubated overnight at room temperature with mouse or rabbit antibodies (Ab) including RMCP-I and mouse II anti-rat mast cell protease (Moredum, Edinburgh, UK), mouse anti-rat macrophages (Serotec, Oxford, UK), and mouse anti-rat granulocytes (Serotec, Oxford, UK). Control slides were treated similarly, applying an irrelevant antibody.

Quantification of immunostaining. Light microscopy was performed using an Optiphot microscope (Nikon, Tokyo, Japan). Cells staining positively with each antibody were counted at the magnification of $\times 200$ in epithelium, submucosa, smooth muscle, and connective tissue. Cell counts were expressed as density, i.e. number of cells $/ \mathrm{mm}^{2}$ of tissue.

Statistical and data analysis. All data are reported as mean \pm SEM except for cell densities, which are expressed as median values. Statistical analysis was performed using the software package NCSS 6.0.21 (Kaysville, UT, U.S.A.). The 
effect of hyperoxic exposure on somatic growth, epithelial thickness, smooth muscle, submucosa, and connective tissue area was assessed by unpaired $t$ test. Two-way ANOVA for repeated measures was used to analyze the effect of hyperoxia on force generation and to determine whether the two curves were different from each other. Differences identified by ANOVA were pinpointed using the Newman-Keuls multiplerange test for individual comparison. Results from immunohistologic studies were analyzed using the Mann-Whitney unpaired test to compare the number of inflammatory cells exposed to hyperoxia versus normoxia. Results were considered significant at $p<0.05$.

\section{RESULTS}

\section{Neonatal Rats}

Effect of hyperoxia on survival and somatic growth. All animals survived. Hyperoxic exposure significantly reduced somatic growth; final weight was $26.9 \pm 0.4 \mathrm{~g}$ in the airexposed group $(n=59)$ versus $21.6 \pm 0.3 \mathrm{~g}$ in the $\mathrm{O}_{2}$-exposed group $(n=59 ; p<0.001)$.

Effect of hyperoxia on tracheal growth and morphometry. Hyperoxia significantly increased the smooth muscle area: $39,000 \pm 1,400 \times \mu \mathrm{m}^{2}$ (air-exposed, $n$ animals $=89$ ) versus $44,000 \pm 1,800 \mu \mathrm{m}^{2}\left(\mathrm{O}_{2}\right.$-exposed, $n$ animals $\left.=89\right) ; p=0.04$. No effect of hyperoxia on the submucosal, connective tissue, or epithelial area was observed. Total tracheal tissue area was not significantly modified in the $\mathrm{O}_{2}$-exposed group $\left(68 \times 10^{4} \pm 2\right.$ $\left.\times 10^{4} \mu \mathrm{m}^{2}, n=37\right)$ versus the air-exposed group $\left(72 \times 10^{4}\right.$ $\left.\pm 2 \times 10^{4} \mu \mathrm{m}^{2}, n=38\right) ; p=0.23$.

Effect of hyperoxia on rat isolated tracheal ring contractility. The mean maximal isometric tension generated in response to carbachol was greater in the trachea from hyperoxiaexposed pups compared with controls (Fig. 1A). However, there was no difference in terms of sensitivity as indicated by $\mathrm{EC}_{50}:-6.82 \pm 0.28 \log \mathrm{M}$ (air-exposed) versus $-6.36 \pm 0.16$ $\log \mathrm{M}\left(\mathrm{O}_{2}\right.$-exposed); $p>0.05$.

After normalization to the smooth muscle cross-sectional area, the concentration-stress curve showed no difference in airway reactivity between the two groups (Fig. 1B). Sensitivity to carbachol also remained unchanged.

Effect of hyperoxia on inflammatory cell infiltration in rat trachea. Light microscopy revealed no alteration in tracheal tissue morphology. Overall inflammatory cell density was significantly increased in the hyperoxic connective tissue only (mean, $24.31 \pm 39.33$ cells $/ \mathrm{mm}^{3}$ in the hyperoxic group versus $5.99 \pm 14.75$ cells $/ \mathrm{mm}^{3}$ in the normoxic group; median, 0 in both groups); $p=0.01$. A significant increase in macrophages was noted in the hyperoxic group in the whole tracheal section (Fig. 2A). When each histologic layer was studied separately, connective tissue-type mast cell (RMCP-I) and macrophage densities were found significantly higher in both submucosa and connective tissue in $\mathrm{O}_{2}$-exposed specimens compared with control (Fig. 2B) (RMPC-I in connective tissue, $18.40 \pm 6.83$ versus $56.64 \pm 11.4$ in the normoxic and hyperoxic groups, respectively). Density of granulocytes was also increased in this latter tissue (Fig. 2B). No mucosal-type mast cell marker (RMCP-II) was detected in either group.
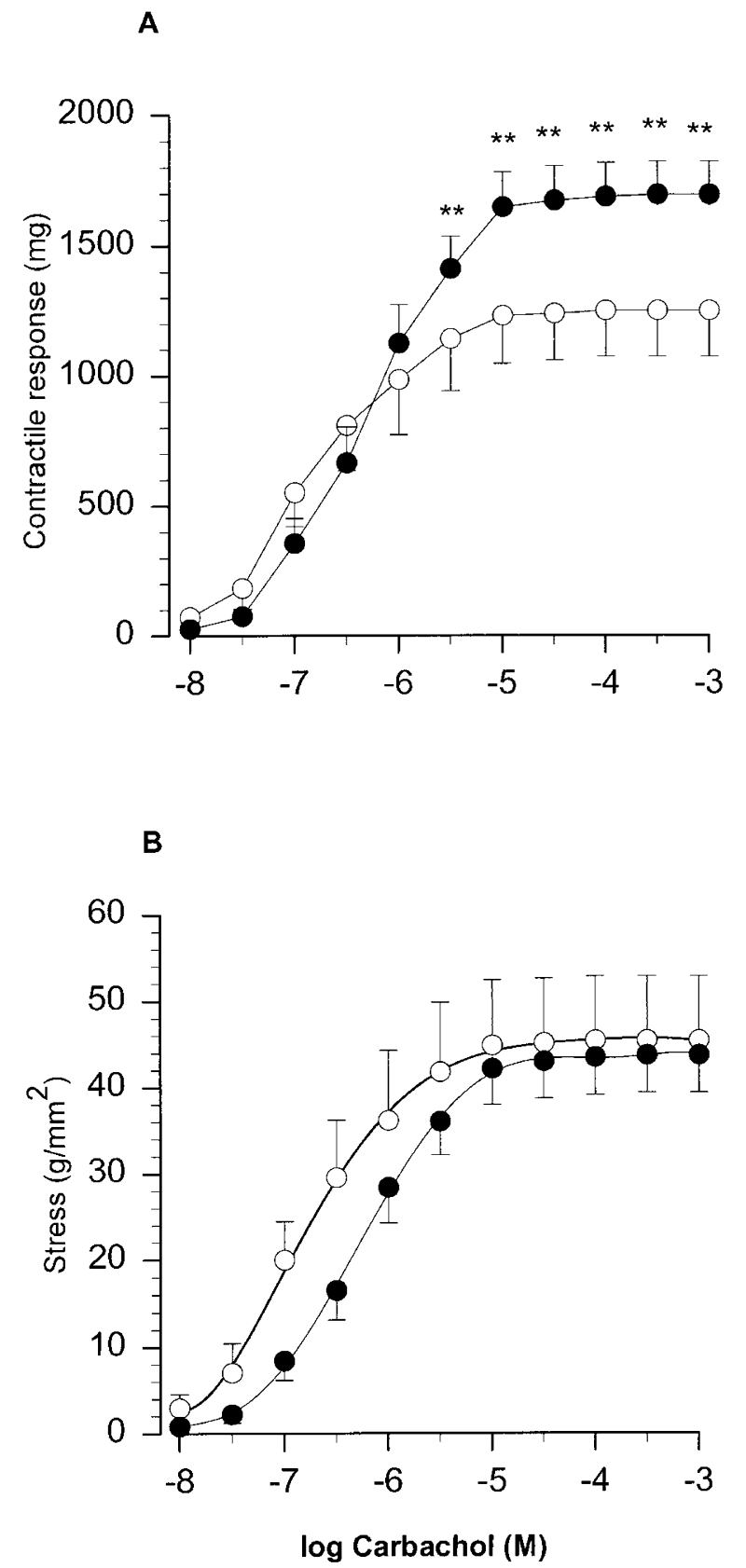

Figure 1. Effects of exposure to $\mathrm{O}_{2}\left(\mathrm{FiO}_{2}, 50 \%\right)$ during $15 \mathrm{~d}$ on the cumulative concentration-response curve $(C C R C)$ to carbachol in newborn rat isolated tracheal rings. Filled symbols indicate mean values of contractile force in the $\mathrm{O}_{2}$-exposed group $(n=8)$. Open symbols indicate mean values for the air-exposed group control $(n=8)$. Vertical bars indicate SEM. $(* * p<0.01)$. (A) Contractile force expressed as active force $(\mathrm{mg})$. (B) Contractile force corrected for cross-sectional area (stress, $\mathrm{g} / \mathrm{mm}^{2}$ ).

\section{Adult Rats}

In contrast with newborn rats, we did not observe any significant difference between the two groups in terms of smooth muscle area, 69,000 $\pm 440 \mu \mathrm{m}^{2}$ (air-exposed, $n=45$ ) versus $75,000 \pm 40\left(\mathrm{O}_{2}\right.$-exposed, $\left.n=37\right)$, or in terms of submucosal, connective tissue, or epithelial surface area (data not shown).

No difference was noted in airway contractile response to carbachol expressed either in terms of active force $\left[\mathrm{E}_{\max }, 2510\right.$ 
A
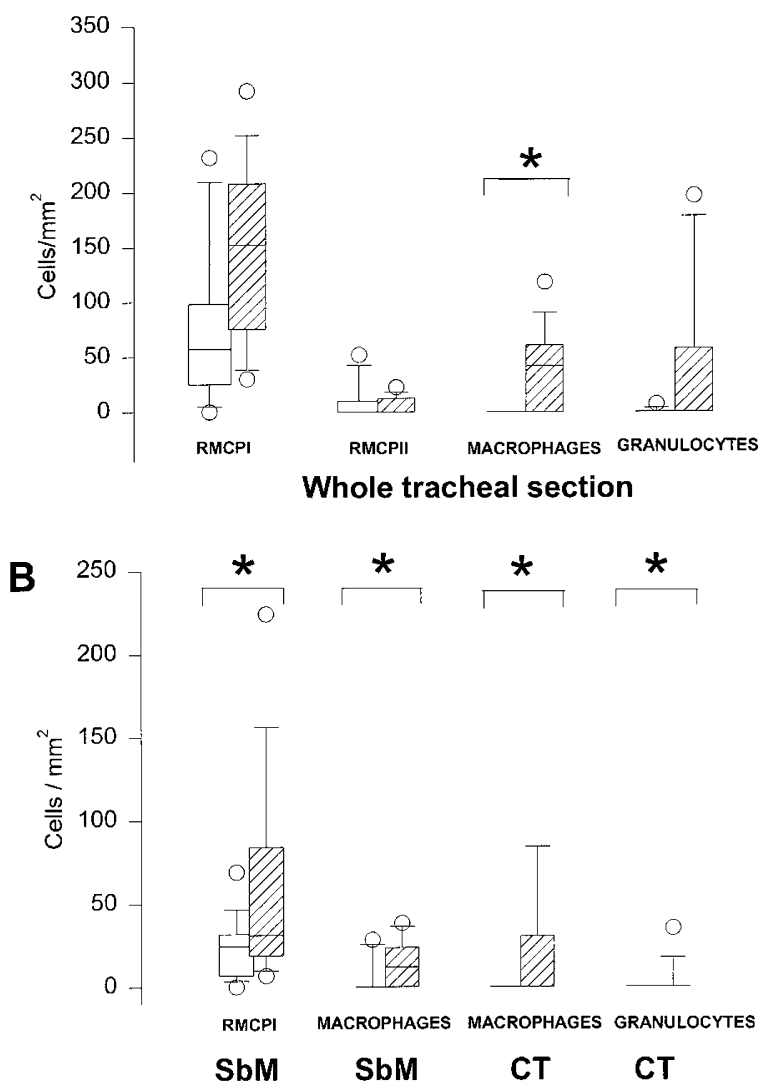

Figure 2. Cell phenotypes detected by MAb in GMA-embedded air-exposed specimens (white box) or $\mathrm{O}_{2}$-exposed specimens (striped box). Antibodies used were anti-connective tissue rat mast cells (RMCP-I), anti-mucosal rat mast cells (RMCP-II), anti-macrophages, and anti-granulocytes. Inflammatory cell numbers were determined in the whole tracheal section (air-exposed, $n=45$; $\mathrm{O}_{2}$-exposed, $\left.n=40\right)(A)$ or according to cell type and histologic layer: anti-connective tissue rat mast cells ( $n=12$ per group), anti-macrophages (air-exposed, $n=12 ; \mathrm{O}_{2}$-exposed, $n=8$ ), and anti-granulocytes ( $n=10 \mathrm{per}$ group) $(B)$. Box and whisker plots: vertical lines represent the 5th and 95th centile points, and circles represent the range. $S b M$ indicates submucosa; $C T$, connective tissue; $* p<0.05$.

$\pm 314 \mathrm{mg}$ (air-exposed) versus $2707 \pm 242 \mathrm{mg}\left(\mathrm{O}_{2}\right.$-exposed)] or in terms of stress $\left[\mathrm{E}_{\max }, 42.10 \pm 5.93 \mathrm{~g} / \mathrm{mm}^{2}\right.$ (air-exposed) versus $38.53 \pm 7.43 \mathrm{~g} / \mathrm{mm}^{2}\left(\mathrm{O}_{2}\right.$-exposed)]. Similarly, sensitivity was not modified by $\mathrm{O}_{2}$ exposure $\left[\mathrm{EC}_{50},-7.12 \pm 0.67\right.$ $\log \mathrm{M}$ (air-exposed) versus $-6.24 \pm 0.06 \log \mathrm{M}\left(\mathrm{O}_{2}\right.$ exposed)]; $p=0.21$.

There was no evidence of increased airway inflammation after hyperoxia, because there was no difference between the two groups in the distribution of inflammatory cells either in the whole tracheal section or in the different histologic layers.

\section{DISCUSSION}

The present study indicates that a moderate and prolonged hyperoxia in neonatal rats induces tracheal smooth muscle thickening leading to enhanced contractility. Hyperoxia also stimulates a cellular inflammatory reaction in the submucosa and connective tissue. The deleterious effects of such $\mathrm{O}_{2}$ exposure are restricted to newborn rats because neither functional nor histologic alterations were observed in the adult rats.
In the present study, the increased contractility observed in the hyperoxic rat pups compared with the normoxic group is in agreement with previous studies reporting that hyperoxia at a much higher level causes pulmonary dysfunction in many animals. For example, it increases maximal airway contractility in newborn guinea pigs (14) and immature rats with increased smooth muscle (15). In premature infants, artificial ventilation results in a greater increase in smooth muscle occurring as soon as $6 \mathrm{~d}$ after birth (16).

We did not address the question of whether hypertrophia or hyperplasia is responsible for smooth muscle thickening. Because the increased density of inflammatory cells was only observed in the submucosa and connective tissue, it is highly unlikely that muscle thickening was due to cellular infiltration. A hyperplastic process resulting in airway epithelial and smooth muscle layer thickening induced by high $\mathrm{O}_{2}$ exposure in immature rats has been demonstrated by cellular DNA synthesis (17). Furthermore, the lungs of $\mathrm{O}_{2}$-exposed rats showed excess airway smooth muscle mitogenic activity, attributable to the presence of one or more non-PDGF (plateletderived growth factor) polypeptide growth factor(s) (18). It is possible that this abnormal mitogenic activity is essential to $\mathrm{O}_{2}$-induced airway smooth muscle remodeling observed in immature rats in vivo.

Similar to what we observed, airway remodeling has previously been described in BPD (1) and asthma (19). The question that arises is whether airway remodeling accounts for hyperoxia-induced airway hyperresponsiveness. In the present study, normalizing tension by the smooth muscle area abolished the difference in the reactivity for carbachol of the airways between the two groups of pup rats. This indicates that smooth muscle remodeling induced by hyperoxia contributes, at least, to the increase in reactivity of the airways. Hershenson et al. (5) have also demonstrated that there is a good correlation between airway hyperresponsiveness and the magnitude of airway layer remodeling. All of the above support the view that airway remodeling greatly influences airway responsiveness in these animals (20).

The following issue deals with the mechanism responsible for the airway remodeling that accompanies hyperoxia in the neonatal rat. The inflammatory reaction observed in the present model, as in BPD, is characterized by the presence of inflammatory cells able to release various inflammatory mediators including proteases, chemoattractants, cytokines, and leukotrienes (21). Interestingly, no increase in epithelial surface area or inflammatory cell recruitment was noted in our study, indicating that it is more likely that the changes were due to tissue rather than purely epithelial hyperoxia. The increase in mastocytes and macrophages in the connective tissue and submucosa as well as in granulocytes in the connective tissue may indirectly contribute to airway remodeling by releasing mitogenic factor(s). Interestingly, Lyle et al. (22) have demonstrated tryptase-positive mast cell hyperplasia in BPD. It is thus possible that the protease revealed by RMCP-I has mitogenic properties that may be partially or totally responsible for muscle thickening. Of note, mucosal-type mastocytes revealed by anti-RMCP-II antibodies do not appear until the age of 3 wk, which is why they were undetectable in our neonatal 
model (23). Tachykinins, substance $\mathrm{P}$, and both neurokinin A and $\mathrm{B}$ have also been implicated in the mediation of neurogenic inflammation of the airways (24-26). Several lines of evidence indicate that hyperoxia may increase tachykinin synthesis in newborn airways, leading to airway remodeling $(8,26)$. Whether a similar phenomenon occurs in our model deserves further studies.

The absence of deleterious effects of moderate hyperoxia in adults suggests that 1 ) such mechanisms were not involved in the present study and 2) rat pups are more prone to oxygen toxicity, probably due to the immaturity of their protective systems (antiproteases, antioxidants, surfactant system) and/or defective immune response (21).

In the present study, a fixed duration of exposure to $\mathrm{O}_{2}$ of $15 \mathrm{~d}$ was chosen a priori because it has practical clinical implications. Because each animal has its own individual susceptibility to inhaled toxic substances (27), this could explain the scatter observed in the inflammatory cell counts. The variability may also have been enhanced by the young age of the animals, which are still in the process of airway maturation. However, we had no objective signs to determine when to cease exposure to have a uniform set of subjects (27).

\section{CONCLUSION}

To the best of our knowledge, this is the first study demonstrating that in rat neonates, a moderate hyperoxia $\left(\mathrm{FiO}_{2}=\right.$ $50 \%$ ) for a relatively long period induces functional, morphometric, and inflammatory alterations similar to those observed in human BPD. Our findings suggest that exposure to $\mathrm{O}_{2}$ induces airway smooth muscle remodeling responsible for airway hyperreactivity. Cellular inflammation appears to participate in this airway remodeling, presumably through the release of mitogenic factors. But the mechanisms that account for a change in function resulting from hyperoxia are only speculative and not defined in this study. Further studies are required to identify the mitogenic factor(s) involved. We believe that this model may prove useful to study the mechanisms of smooth muscle remodeling and to test therapeutic interventions relevant to the treatment of BPD.

Acknowledgments. The authors thank B. Martinez, H. Crevel, and P. Téchoueyres for technical assistance and J.L. Lachaud for the design and monitoring of the hyperoxia exposure chambers.

\section{REFERENCES}

1. Northway Jr WH, Rosan RC, Porter DY 1967 Pulmonary disease following respirator therapy of hyaline-membrane disease. Bronchopulmonary dysplasia. N Engl J Med 276:357-368
2. Fukunaga T, Davies P, Zhang L, Hashida Y, Motoyama EK 1998 Prolonged high intermittent positive-pressure ventilation induces airway remodeling and reactivity in young rats. Am J Physiol 275:L567- L573

3. Davis JM, Dickerson B, Metlay L, Penney DP 1991 Differential effects of oxygen and barotrauma on lung injury in the neonatal piglet. Pediatr Pulmonol 10:157-163

4. Stocker JT 1986 Pathologic features of long-standing "healed" bronchopulmonary dysplasia: a study of 28 3- to 40-month-old infants. Hum Pathol 17:943-961

5. Hershenson MB, Garland A, Kelleher MD, Zimmermann A, Hernandez C, Solway J 1992 Hyperoxia-induced airway remodeling in immature rats. Correlation with airway responsiveness. Am Rev Respir Dis 146:1294-1300

6. Szarek JL 1989 In vivo exposure to hyperoxia increases airway responsiveness in rats. Demonstration in vivo and in vitro. Am Rev Respir Dis 140:942-947

7. Szarek JL, Ramsay HL, Andringa A, Miller ML 1995 Time course of airway hyperresponsiveness and remodeling induced by hyperoxia in rats. Am J Physiol 269:L227-L233

8. Agani FH, Kuo NT, Chang CH, Dreshaj IA, Farver CF, Krause JE, Ernsberger P, Haxhiu MA, Martin RJ 1997 Effect of hyperoxia on substance P expression and airway reactivity in the developing lung. Am J Physiol 273:L40-L45

9. Young TE, Kruyer LS, Marshall DD, Bose CL 1999 Population-based study of chronic lung disease in very low birth weight infants in North Carolina in 1994 with comparisons with 1984. North Carolina Neonatologists Association Pediatrics 104:e17

10. Roux E, Guibert C, Crevel H, Savineau JP, Marthan R 1996 Human and rat airway smooth muscle responsiveness after ozone exposure in vitro. Am J Physiol 271:L631L636

11. Mitchell RW, Kelly E, Leff AR 1991 Effect of in vitro preconditioning on tracheal smooth muscle responsiveness. Am J Physiol 260:L168-L173

12. Berger P, Walls AF, Marthan R, Tunon de Lara JM 1998 Immunoglobulin E-induced passive sensitization of human airways: an immunohistochemical study. Am J Respir Crit Care Med 157:610-616

13. Britten KM, Howarth PH, Roche WR 1993 Immunohistochemistry on resin sections: a comparison of resin embedding techniques for small mucosal biopsies. Biotech Histochem 68:271-280

14. Uyehara CF, Pichoff BE, Sim HH, Uemura HS, Nakamura KT 1993 Hyperoxic exposure enhances airway reactivity of newborn guinea pigs. J Appl Physiol $74: 2649-2654$

15. Hershenson MB, Aghili S, Punjabi N, Hernandez C, Ray DW, Garland A, Glagov S, Solway J 1992 Hyperoxia-induced airway hyperresponsiveness and remodeling in immature rats. Am J Physiol 262:L263-L269

16. Hislop AA, Haworth SG 1989 Airway size and structure in the normal fetal and infant lung and the effect of premature delivery and artificial ventilation. Am Rev Respir Dis 140:1717-1726

17. Hershenson MB, Kelleher MD, Naureckas ET, Abe MK, Rubinstein VJ, Zimmermann A, Bendele AM, McNulty JA, Panettieri RA, Solway J 1994 Hyperoxia increases airway cell S-phase traversal in immature rats in vivo. Am J Respir Cell Mol Biol 11:296-303

18. Naureckas ET, Hershenson MB, Abe MK, Kelleher MD, Florio C, Heisler SI, Absher M, Evans JN, Samsel RW, Solway J 1995 Bronchoalveolar lavage fluid from immature rats with hyperoxia-induced airway remodeling is mitogenic for airway smooth muscle. Am J Respir Cell Mol Biol 12:268-274

19. Bento AM, Hershenson MB 1998 Airway remodeling: potential contributions of subepithelial fibrosis and airway smooth muscle hypertrophy/hyperplasia to airway narrowing in asthma. Allergy Asthma Proc 19:353-358

20. Hershenson MB, Abe MK, Kelleher MD, Naureckas ET, Garland A, Zimmermann A, Rubinstein VJ, Solway J 1994 Recovery of airway structure and function after hyperoxic exposure in immature rats. Am J Respir Crit Care Med 149:1663-1669

21. Groneck P, Speer CP 1995 [Pathogenesis of bronchopulmonary dysplasia]. Z Geburtshilfe Neonatol 199:181-189

22. Lyle RE, Tryka AF, Griffin WS, Taylor BJ 1995 Tryptase immunoreactive mast cell hyperplasia in bronchopulmonary dysplasia. Pediatr Pulmonol 19:336-343

23. Wilkes LK, McMenamin C, Holt PG 1992 Postnatal maturation of mast cell subpopulations in the rat respiratory tract. Immunology 75:535-541

24. Noveral JP, Grunstein MM 1995 Tachykinin regulation of airway smooth muscle cell proliferation. Am J Physiol 269:L339-L343

25. Hershenson MB, Doolan A, White SR, Solway J 1994 Effect of capsaicin pretreatment on hyperoxia-induced airway remodeling in immature rats. Am Rev Respir Dis 149:A304(abstr)

26. Yohannan MR, Miller MJ, Dreshaj LA, Agani FH, Ernsberger P 1995 Hyperoxia and barotrauma up-regulate neurokinin-1 receptor binding in neonatal porcine respiratory tract. Am J Crit Care Med 151:A438(abstr)

27. Marinkovich GA, Pichoff BE, Iwamoto LM, Dressel MV, Nakamura KT 1995 Acute hyperoxic injury attenuates the relaxing effects of "loop" diuretics and salbutamol on large airways of newborn guinea pigs. Pediatr Res 38:280-285 